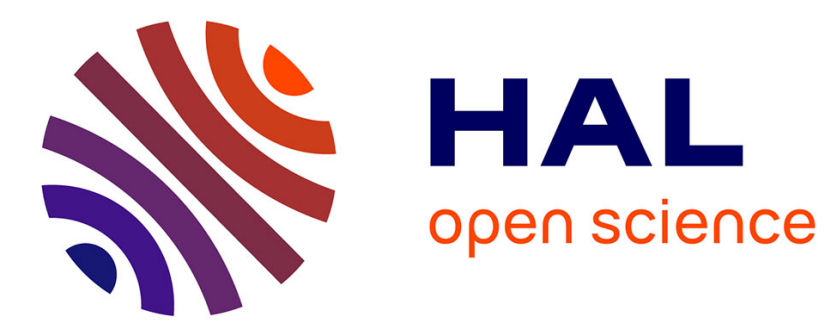

\title{
Synthesis of Heterospirocycles through Gold-(I) Catalysis, Useful Building Blocks for Medicinal Chemistry
}

Kossi Efouako Soklou, Hamid Marzag, Béatrice Vallée, Sylvain Routier, Karen Plé

\section{To cite this version:}

Kossi Efouako Soklou, Hamid Marzag, Béatrice Vallée, Sylvain Routier, Karen Plé. Synthesis of Heterospirocycles through Gold-(I) Catalysis, Useful Building Blocks for Medicinal Chemistry. Advanced Synthesis and Catalysis, 2021, 10.1002/adsc.202101080 . hal-03411162

HAL Id: hal-03411162

https://hal.science/hal-03411162

Submitted on 13 Dec 2021

HAL is a multi-disciplinary open access archive for the deposit and dissemination of scientific research documents, whether they are published or not. The documents may come from teaching and research institutions in France or abroad, or from public or private research centers.
L'archive ouverte pluridisciplinaire HAL, est destinée au dépôt et à la diffusion de documents scientifiques de niveau recherche, publiés ou non, émanant des établissements d'enseignement et de recherche français ou étrangers, des laboratoires publics ou privés. 
This is the pre-peer reviewed version of the following article: Soklou, K.E., Marzag, H., Vallée, B., Routier, S. and Plé, K. (2021), Synthesis of Heterospirocycles through Gold-(I) Catalysis: Useful Building Blocks for Medicinal Chemistry, which has been published in final form at http://doi.org/10.1002/adsc.202101080. This article may be used for non-commercial purposes in accordance with Wiley Terms and Conditions for Use of Self-Archived Versions.

\title{
Synthesis of Heterospirocycles through Gold-(I) Catalysis, Useful Building Blocks for Medicinal Chemistry
}

\author{
Kossi Efouako Soklou, ${ }^{\mathrm{a}}$ Hamid Marzag, ${ }^{\mathrm{a}}$ Béatrice Vallée, ${ }^{\mathrm{b}}$ Sylvain Routier ${ }^{\text {a* }}$ and Karen \\ Plé ${ }^{\text {a* }}$ \\ a Institut de Chimie Organique et Analytique, University of Orléans, CNRS UMR 7311, \\ 45067 Orléans Cedex 2, France. Phone: +33 (0)2 38417354 \\ Email: sylvain.routier@univ-orleans.fr, karen.ple@univ-orleans.fr \\ b Centre de Biophysique Moléculaire, CNRS, UPR 4301, University of Orléans and INSERM, 45071 Orléans Cedex 2 , \\ France
}

\begin{abstract}
Gold-(I) catalysis was used for the intramolecular cyclization of tertiary alcohols with terminal alkynes to form diverse aza-spirocycles. The reaction was carried out with low catalyst loading under microwave irradiation to give both sulfonylated and acylated spirocyclic nitrogen derivatives. Gram scale spirocyclization was carried out and demonstrates the robustness of the reaction. An intramolecular MizorokiHeck reaction was performed to give several tetracyclic spirocycles. Double bond reduction and selective protecting group manipulation gave spiropiperazine and spiromorpholine derivatives. These compounds were incorporated into biologically relevant scaffolds to give the first selective spirocyclic inhibitors of LIMK.
\end{abstract}

\section{Introduction}

The quest for molecular diversity in drug discovery is still ongoing, with the exploration of only a fraction of the available chemical and biological space. ${ }^{[1]}$ As a result, the pharmaceutical industry continues to search for innovative methods and unique scaffolds to expand this chemical space and generate innovative compounds with improved activities and good ADME-Tox profiles. In the past decades, diversity has been developed through the wide spread use of nitrogen and oxygen $\mathrm{Csp}^{3}$-rich saturated heterocycles. This contributes to an additional 3D molecular shape, and has been shown to favorably influence certain pharmacokinetic properties. ${ }^{[2]}$ It is now recognized that the presence of quaternary carbon centers and a higher fraction of $\mathrm{sp}^{3}$ carbons $\left(\mathrm{Fsp}^{3}\right)$ are advantageous in the discovery of new drugs. ${ }^{[3]}$ The incorporation of spirocycles in biologically relevant compounds adds an additional level of molecular complexity and diversity favorable for this process. ${ }^{[4]}$ Spirocycles are characterized by the presence of a fully substituted $\mathrm{sp}^{3}$ carbon which defines a well-organized three-dimensional (3D) orthogonal structure. In addition, their increased C$\mathrm{sp}^{3}$ count also make them interesting candidates for early lead and drug optimization, as well as fragment based drug design. ${ }^{[5]}$ In particular, $N$ -

heterospirocycles allow additional functionalization along well-defined axes, which increases the potential for fragment growth in multiple directions. ${ }^{[6]}$

To date, and despite an increasing number of spirocyclic drugs (Figure 1), ${ }^{[4 a]}$ the synthesis of these compounds with heteroatoms directly attached to the spirocyclic carbon remains challenging.

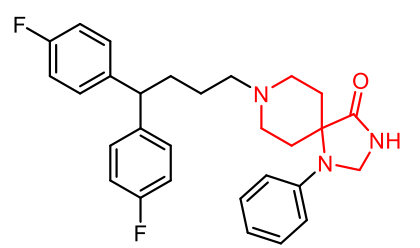

Fluspirilene

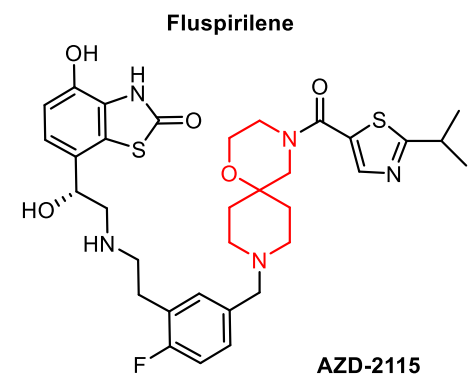

Figure 1. Examples of approved and late clinical trial spirocyclic drugs.

In our recent work, we have developed a gold(I) catalyzed cyclization reaction which gives access to a variety of $\mathrm{N}$ - and $\mathrm{O}$ - heterospirocycles starting 
from tertiary alcohols and the corresponding protected amines. ${ }^{[7]}$ Herein we have extended this methodology to the preparation of polyfunctional aza-spirocycles A (Figure 2). These chemical "building blocks" can then be orthogonally deprotected for functionalization or incorporation into medicinal chemistry scaffolds. In addition, the presence of a halogen atom on several of the newly designed spirocyclic compounds led us to perform an intramolecular Mizoroki-Heck reaction giving access to original tetracyclic structures $\mathbf{B}$. This is a further contribution to the expansion of the spirocyclic chemical space. ${ }^{[8]}$

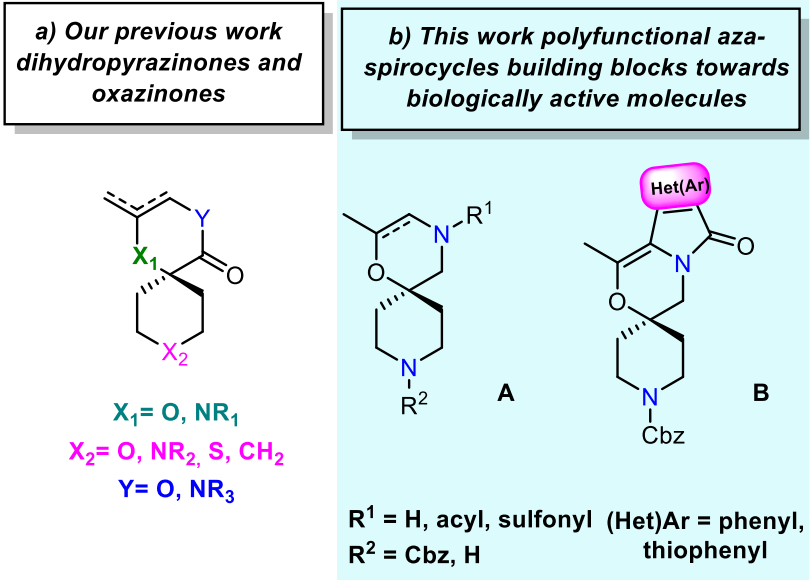

Figure 2. Previous work (a) and this work (b) giving access to new aza-spirocycles (A and $\mathbf{B})$.

\section{Results and Discussion}

We first prepared epoxide 1 from commercially available 1-(benzyloxy carbonyl)-4-piperidinone. ${ }^{[7]}$ Selective ring opening with $N$-methylpropargyl amine in ethanol at $25{ }^{\circ} \mathrm{C}$ gave compound 2 in $93 \%$ yield (Scheme 1). Using the same conditions with propargyl amine gave the desired alkyne derivative $\mathbf{3}$ in $82 \%$ yield, but with a reaction time of 3 days. This epoxide opening was optimized under microwave irradiation using an excess of propargyl amine in the presence of $\mathrm{LiCl}$ to give 3 in a $92 \%$ optimized yield in only 30 minutes. Standard sulfonylation, acylation or benzoylation of the secondary propargyl amine then completed the library of precursors 4-20 (all new compounds are described in the SI).

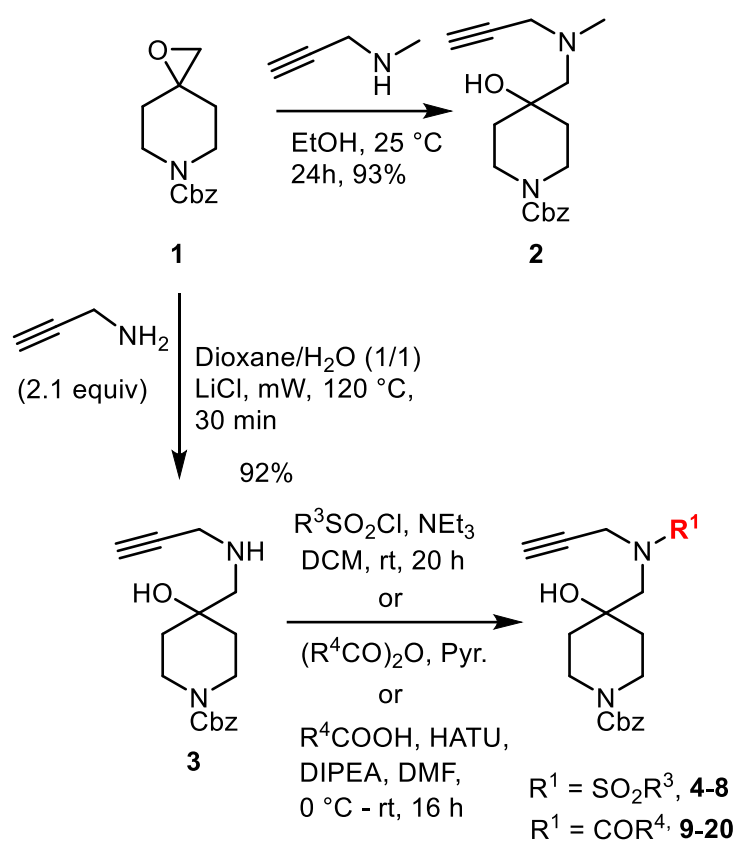

Scheme 1. Preparation of acyl and sulfonyl precursors.

Surprisingly, our first attempts at cyclization were unsuccessful using our previously reported conditions (Scheme 2). No spirocycle was detected with the unprotected amine $\mathbf{3}$ and a complex mixture of products was obtained with a simple methyl substitution $\left(2, \mathrm{R}=\mathrm{CH}_{3}\right)$.

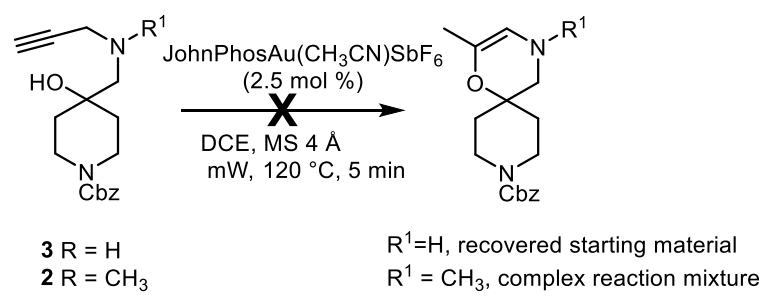

Scheme 2. First attempted cyclization reactions.

Fortunately, the use of sulfonyl precursors 4-8 met with greater success (Table 1). When the newly prepared precursors containing a methanesulfonyl (Ms), benzenesulfonyl, p-toluenesulfonyl (Ts) amide group in the starting substrate underwent cyclization, the endocyclic product was observed in excellent yields (21-23). Nevertheless, this behavior was not systematic, as the presence of a highly deactivating 4nitrobenzenesulfonyl (nosyl) group had a strong influence on cyclization. The ${ }^{1} \mathrm{H}$ NMR of the crude reaction mixture after 5 minutes of microwave irradiation showed incomplete conversion and exclusive formation of an exocyclic double bond. As observed in our first study, total isomerization to an endocyclic double bond adduct is possible in the presence of 10 mol\% PTSA. $\mathrm{H}_{2} \mathrm{O}$. Thus, the direct addition of the acid at the beginning of the reaction gave the spirocycle $\mathbf{2 4}$ in only 5 minutes and $92 \%$ 
yield as the exclusive reaction product. The same behavior was observed during the reaction leading to 25, which was formed in an excellent 95\% yield. Cyclization on a larger scale $(13.0 \mathrm{mmol})$ was equally successful, and we isolated compound $\mathbf{2 3}$ in a $77 \%$ yield.

Table 1. Sulfonylated spirocycles.
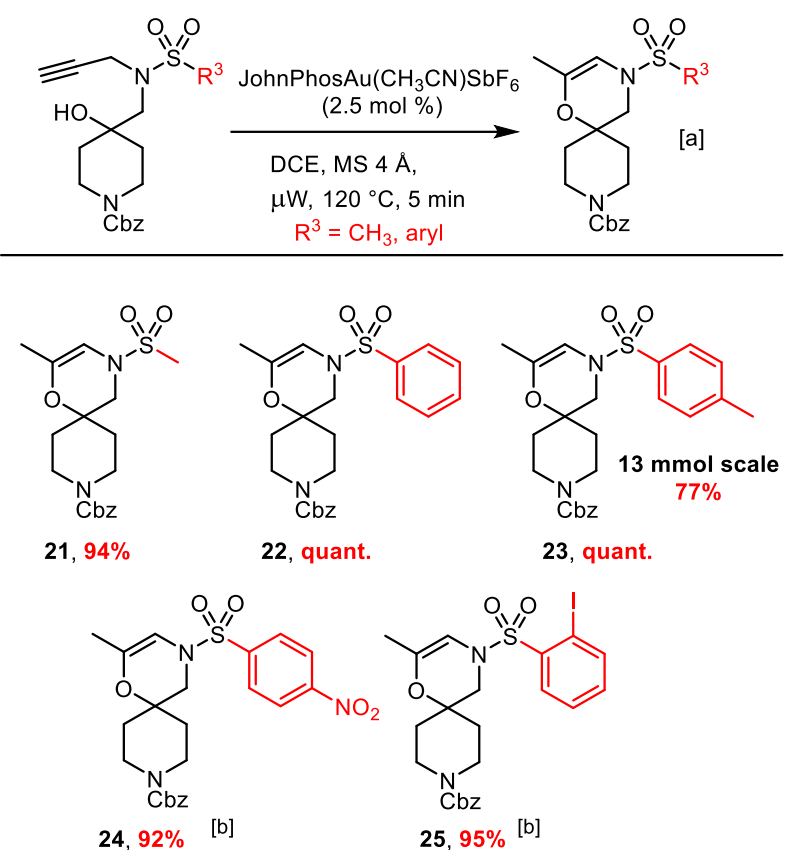

[a] Yields of isolated products are given. [b] $10 \mathrm{~mol} \%$ PTSA. $\mathrm{H}_{2} \mathrm{O}$ was added for complete conversion to the endocyclic double bond.

A last sulfonated derivative was prepared to prove that the cyclization preserved asymmetry and was compatible with commonly used acid labile Oprotecting groups. We synthesized derivative $\mathbf{2 6}$ from quinic acid (see SI for preparation) and cyclization afforded the desired spirocycle $\mathbf{2 7}$ in an excellent 90\% yield (Scheme 3 ).

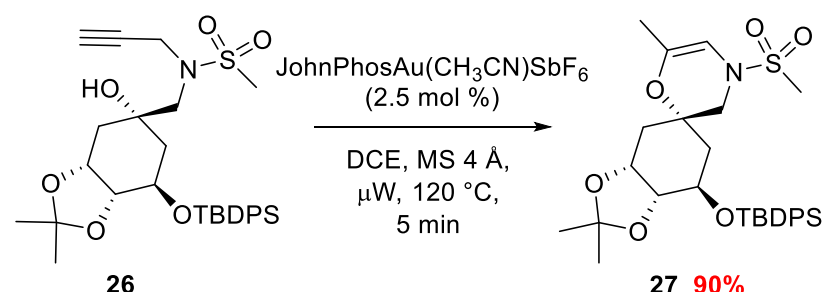

Scheme 3. Cyclization with a protected quinic acid derivative.

Because the reaction worked well with sulfonamides, we then extended our methodology to regular amides, as this functional group is slightly less robust. Cyclization with the acetyl derivative gave only traces of the desired product $\mathbf{2 8}$ whereas with a trifluoroacetyl or a benzoyl group, the reaction occurred without difficulty, and the desired products were obtained in excellent yields (92\% - quantitative). The fleeting nature of the exocyclic product and the need to either eliminate the unreacted starting material or separate the double bond isomers lead us to systematically add a catalytic amount of acid to the reaction mixture before irradiation with these substrates. Interestingly, the presence of the amide group led to a systematic mixture of two conformations ( 40/60). A ${ }^{1} \mathrm{H}$ NMR experiment at $80{ }^{\circ} \mathrm{C}$ (DMSO- $\left.d_{6}\right)$ was performed with the spirocycle 29, but no signal coalescence was detected due certainly to an unattainable high-energy barrier at our limiting temperature. To finish this part of our study, cyclization to give compound $\mathbf{3 8}$ was successfully performed on a $1.0 \mathrm{mmol}$ reaction scale in an excellent $98 \%$ yield.

Table 2. Acylated spirocycles.

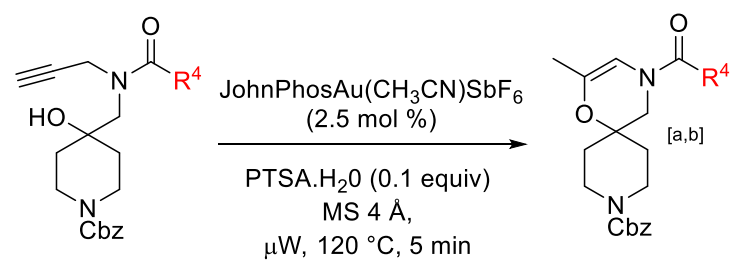

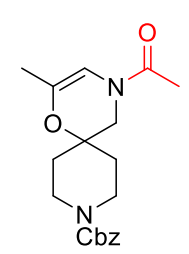

28, trace<smiles>CC1=CN(C(=O)c2ccccc2I)CC2(CCN(C(=O)OC(C)(C)C)CC2)O1</smiles>

31, quant.

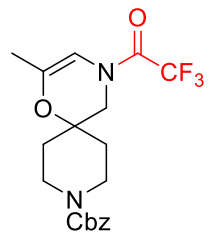

$29,92 \%$

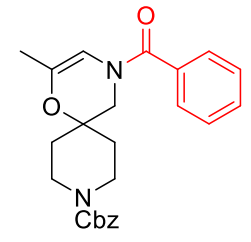

$30,97 \%$

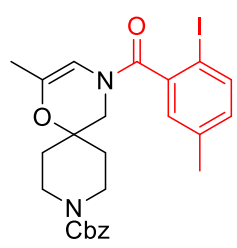

$32,94 \%$<smiles>CC(=O)N1CCC2(CC1)CN(C(=O)c1ccc(C)cc1I)C=C(C)O2</smiles>

$34,96 \%$

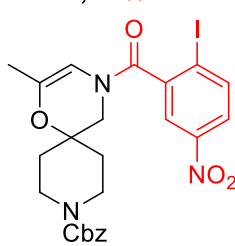

35 , quant.

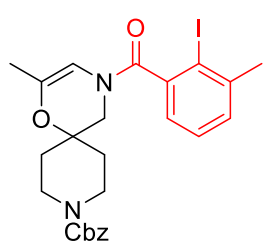

$33,95 \%$

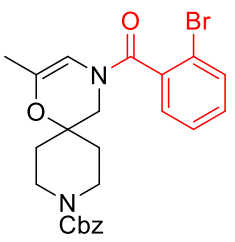

37, quant.

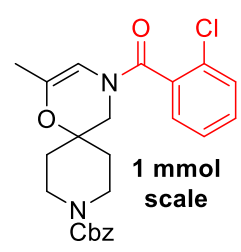

$38,98 \%$

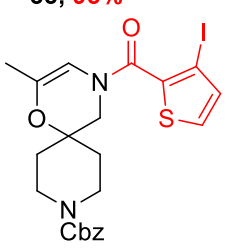

$36,99 \%$

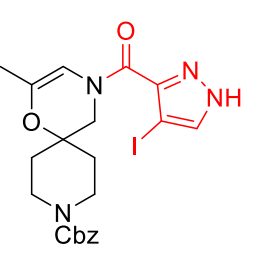

39 , trace 
[a] Yields of isolated products are given; [b] spirocycle detected as 2 conformations in a $\sim 40 / 60$ ratio from ${ }^{1} \mathrm{H}$ NMR spectra.

During our investigation, a limit to our reaction was reached with the alkyne derivative 20 (Scheme 4). The presence of the heteroaromatic $\mathrm{NH}$ group favored a second intramolecular cyclization pathway between the pyrrole and the alkyne. The enhanced reactivity of the nitrogen atom combined with the formation of a completely conjugated heterocycle were all factors in favor of this pathway, which gave compound $\mathbf{4 0}$ in a nearly quantitative yield.

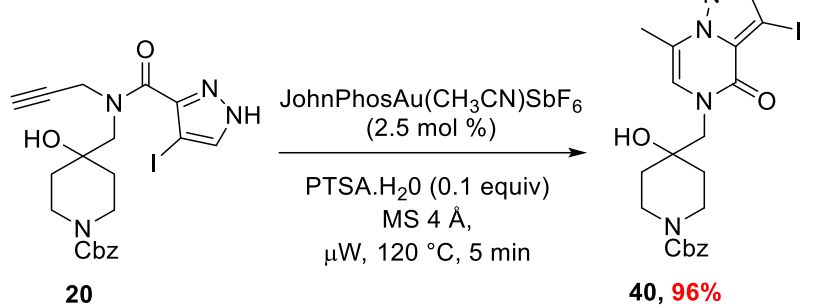

Scheme 4. Intramolecular cyclization of the pyrazole ring

With compounds 31-38 in hand, and the simultaneous presence of a halogen atom and a double bond, we sought to increase molecular diversity through an intramolecular Mizoroki-Heck reaction. Using the microwave conditions described by Trabocchi et al., ${ }^{[9]}$ several tetracyclic spirocycles were prepared in excellent yields (Table 3). The best results were observed with iodine containing substrates. The brominated analog 37 gave poor yields, and the chlorinated derivative $\mathbf{3 8}$ was unreactive with a full recovery of the starting material. According to the reaction mechanism, syn $\beta$-hydride elimination in the last step should have given an exocyclic double bond. Nonetheless, all of the observed products had only an endocyclic one, indicating a spontaneous bond migration to give the favored conjugated product. The reaction was also tried with the corresponding sulfonate derivative $\mathbf{2 5}$, but the reaction was unsuccessful. We hypothesize that the $\mathrm{SO}_{2}$ group did not have the necessary spatial orientation for cyclization to occur.
Table 3. Intramolecular Mizoroki-Heck reaction.

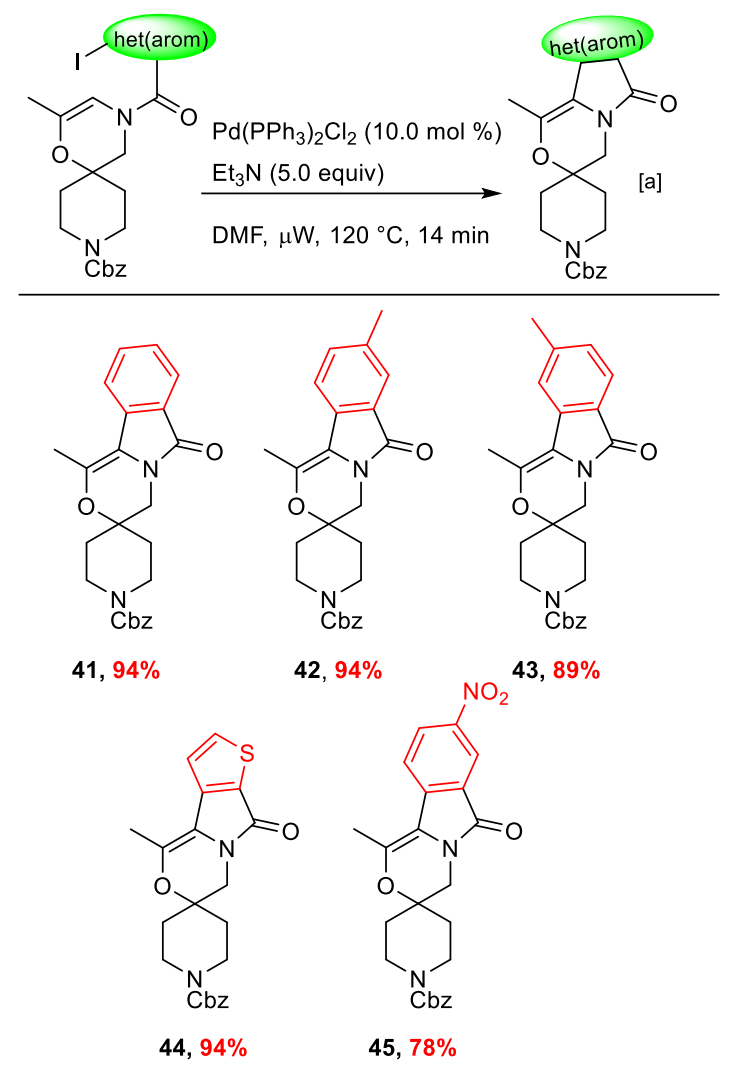

[a] Yields of isolated products are given.

Our next objective was to further functionalize the obtained spirocycles through double bond reduction and selective deprotection of the amino groups. Generating the free amines would allow us to incorporate these compounds into biologically relevant scaffolds. Because of their enamine character and the potential instability of the unsaturated deprotected amine intermediate, we first explored double bond reduction. When compound $\mathbf{2 3}$ was subjected to classical reduction methods no reduction was observed ( $\mathrm{Pt} / \mathrm{C}$ or $\mathrm{Pd} / \mathrm{C}, \mathrm{H}_{2}$ (50 bars); $\mathrm{Pd}(\mathrm{OAc})_{2}$, XantPhos, $\mathrm{HCOOH}, 90^{\circ} \mathrm{C}$ )

If a first attempt at ionic reduction with triethylsilane/ trifluoroacetic acid ${ }^{[10]}$ was unsuccessful (Table 4, entry 1), we found that increasing the triethylsilane to 22.0 equiv. in a mixture of TFA/DCM (50/50) gave successful reduction with no amine deprotection. In a first small scale reaction $(0.2$ $\mathrm{mmol}$ ), the desired spiromorpholine $\mathbf{4 6}$ was obtained in $76 \%$ yield (entry 2). Performing the reaction on a larger scale with an increase in concentration was beneficial to the product yield. We thus obtained $81 \%$ of compound $\mathbf{4 6}$ when the reaction was carried out on a $5.0 \mathrm{mmol}$ scale (entry 3 ), and an $87 \%$ yield on a $10 \mathrm{mmol}$ scale (entry 4$)$. 
Table 4. Optimization of double bond reduction of the sulfonylamide derivative $\mathbf{2 3}$.

\begin{tabular}{|c|c|c|c|}
\hline & 23 & 46 & \\
\hline Entry & Conditions & $\begin{array}{c}\text { Time } \\
\text { (h) }\end{array}$ & $\begin{array}{l}\text { Yield } \\
(\%)^{\mathrm{a})}\end{array}$ \\
\hline 1 & $\begin{array}{c}\text { TFA ( } 10.0 \text { equiv), } \\
\mathrm{Et}_{3} \mathrm{SiH}(6.0 \text { equiv }), 0^{\circ} \mathrm{C} \\
- \text { reflux, DCM }\end{array}$ & 24 & $\mathrm{Nr}^{\mathrm{b})}$ \\
\hline 2 & $\begin{array}{c}\mathrm{Et}_{3} \mathrm{SiH}(22.0 \text { equiv }), \\
0{ }^{\circ} \mathrm{C}-\mathrm{rt}, \\
\mathrm{DCM} / \mathrm{TFA},(1 / 1) \\
\text { Scale }=\mathbf{0 . 0 3} \mathbf{~ m m o l}, \\
\mathbf{C}=\mathbf{0 . 0 2} \mathbf{~ M}\end{array}$ & 1.5 & 76 \\
\hline 3 & $\begin{array}{c}\mathrm{Et}_{3} \mathrm{SiH}(22.0 \text { equiv }), \\
0^{\circ} \mathrm{C}-\mathrm{rt}, \\
\mathrm{DCM} / \mathrm{TFA},(1 / 1) \\
\text { Scale }=\mathbf{5 . 0} \mathbf{~ m m o l}, \\
\mathbf{C}=\mathbf{0 . 0 6} \mathbf{~ M}\end{array}$ & 1.5 & 81 \\
\hline 4 & $\begin{array}{c}\mathrm{Et}_{3} \mathrm{SiH}(22.0 \text { equiv }), \\
0{ }^{\circ} \mathrm{C}-\mathrm{rt}, \\
\mathrm{DCM} / \mathrm{TFA},(1 / 1) \\
\text { Scale }=\mathbf{1 0} \mathbf{~ m m o l}, \\
\mathbf{C}=\mathbf{0 . 1} \mathbf{~ M}\end{array}$ & 3 & 87 \\
\hline
\end{tabular}

a) isolated yield. b) $\mathrm{Nr}$ : no reaction, recovered starting material.

This reaction was however capricious when applied to other amide derivatives (29 and 30) (Table 5) as no reaction occurred. We observed partial degradation and recovery of the starting material in spite of different optimization attempts. Reduction of the double bond in derivative $\mathbf{3 8}$ proved to be more successful. The saturated derivative $\mathbf{4 7}$ was isolated in good yield $(83 \%)$ with an optimized reaction concentration of $0.04 \mathrm{M}$ on a small or medium scale $(2.7 \mathrm{mmol})$. A slow addition of TFA and an increase in reaction time to $24 \mathrm{~h}$ was necessary for complete conversion.
Table 5. Double bond reduction
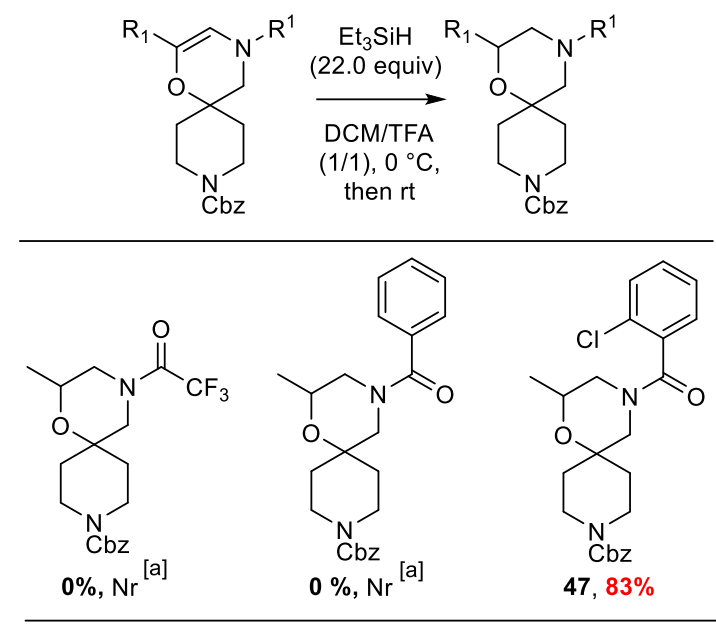

a) $\mathrm{Nr}:$ No reaction.

We then performed a selective removal of the carbobenzyloxy $(\mathrm{Cbz})$ group by hydrogenation in the presence of palladium chloride in excellent yield for both substrates (Scheme 5). Removal of the tosyl group in the presence of the $\mathrm{Cbz}$ protected nitrogen was unsuccessful whatever the method used. Nevertheless, the required orthogonality leading to the spiromorpholine moiety was found with the saturated spirocycle 47. The successful cleavage of the acyl group (2-ClBz) was performed with lithium triethylborohydride $^{[11]}$ to give compound $\mathbf{5 0}$ in $67 \%$ yield with no loss of the carbamate function.

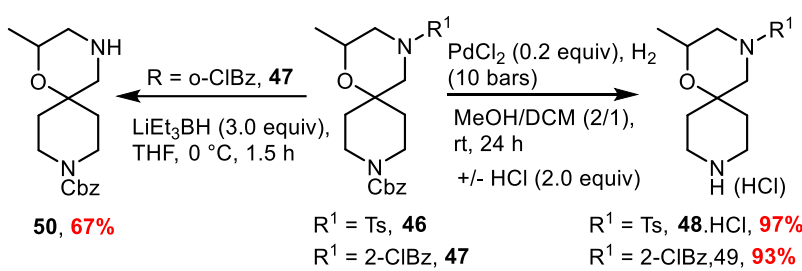

Scheme 5. Nitrogen protecting group manipulation

As our ultimate goal was to design biologically active spirocyclic molecules, the aza-spirocycle was then integrated into one of our on-going medicinal chemistry research projects for kinase inhibition. The hydrochloride salt 48 was reacted with the aromatic chloride $\mathbf{5 1}^{[12]}$ to give the 4-amino pyrrolopyrimidine 52 in a 95\% optimized yield (Scheme 6). Reductive removal of the tosyl group was then possible in the presence of sodium/naphthalene salt, to give the free amine $\mathbf{5 3}$ in 52\% yield. Urea formation leading to the final products followed a two-step process, activation of the desired aniline with 4-nitrochlorofomate, followed by reaction with the spirocycle $\mathbf{5 3}$ to give the desired products (56 and $\mathbf{5 7}$ ) in a modest $31 \%$ yield. 


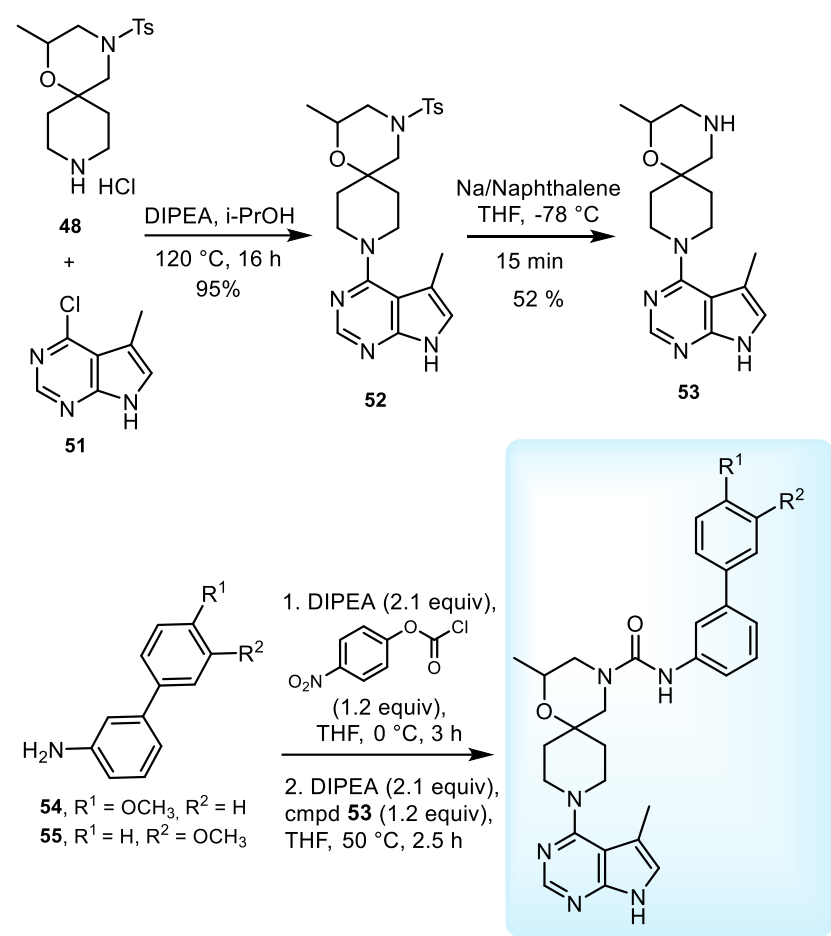

56, $\mathrm{R}^{1}=\mathrm{OCH}_{3}, \mathrm{R}^{2}=\mathrm{H}, 31 \%$ 57, $R^{1}=H, R^{2}=O_{3}, 31 \%$

Scheme 6. Synthesis of potential Lim kinase inhibitors.

Inhibition tests against Lim kinases (LIMK) were performed with derivatives 56 and $\mathbf{5 7}$. IC I0 $_{50}$ values of 197 and $87 \mathrm{nM}$ were obtained respectively for the two compounds, and clearly showed the favorable interactions of both molecules with the LIMK1 catalytic pocket. This encouraging result for designing other spirocyclic LIMK1 inhibitors was reinforced by the impressive selectivity observed for these two compounds against the parent enzyme ROCK 1 (\% inhibition at $10 \mu \mathrm{M}=13$ and 5 respectively) and ROCK 2 (\% inhibition at $10 \mu \mathrm{M}=$ 3 and 2 respectively).

\section{Conclusion}

In conclusion, our goal of generating molecular diversity was achieved through the synthesis of 22 new aza-spirocycles via the high yielding gold catalyzed cyclization of tertiary alcohols with terminal alkynes. The reaction was carried out with low catalyst loading under microwave irradiation to give both sulfonylated and acylated spirocyclic nitrogen derivatives. The spirocyclization reaction could be performed on several different scales, on micromolar amounts up to $13 \mathrm{mmol}$ in good to excellent yields. Increased molecular diversity was achieved through an intramolecular Mizoroki-Heck reaction to give five new tricyclic spirocycles. Double bond reduction and selective protecting group manipulation were successfully explored, with reduction being carried out on up to $10 \mathrm{mmol}$ of the starting material. Selective deprotection led to two different reactive sites i.e. the nitrogen of the spiropiperazine and that of the spiromorpholine. With this orthogonal sequence in hand, we then successfully prepared the first selective spirocyclic inhibitors of LIMK1 thus opening up an opportunity for the continuation of this work in a medicinal chemistry program.

\section{Experimental Section}

General procedure for the gold-(I) catalyzed cyclization reaction: To a solution of the substrate (1.00 equiv.) in anhydrous 1,2-dichloroethane $(\mathrm{C}=0.06 \mathrm{M})$ under argon, were added $4 \AA$ molecular sieves and JohnPhosAu$\left(\mathrm{CH}_{3} \mathrm{CN}\right) \mathrm{SbF}_{6}$ (0.025 equiv.). The mixture was then irradiated in a microwave oven at $120^{\circ} \mathrm{C}$ for $5 \mathrm{~min}$. After completion, the reaction was filtered over diatomaceous earth, the solvent was removed under reduced pressure, and the residue was purified by silica gel column chromatography. In the modified cyclization reaction PTSA. $\mathrm{H}_{2} \mathrm{O}$ (0.10 equiv.) was added before microwave irradiation.

\section{Acknowledgements}

The authors would like to thank the Région Centre Val de Loire (APR-IR Licorne, PhD funding K. SOKLOU) which made this study possible, as well as the ANR CliNeF1 (ANR_19_CE18), CNRS innovation et C-Valo (Pélican) for their financial support. In addition, the projects Valbiocosm (FEDER-FSE 2017EX003202), CHemBio (FEDER-FSE 2014-2020-EX003677), Techsab (FEDER-FSE 2014-2020-EX011313), the RTR Motivhealth (2019-00131403), the Labex programs SYNORG (ANR-11-LABX-0029) and IRON (ANR-11-LABX-0018-01), and the Ligue contre le Cancer du Grand Ouest (comités des Deux Sèvres, du Finistère, de l'Ile et Villaine, du Loir et Cher, de Loire Atlantique, du Loiret, de la Vienne) are also gratefully acknowledged for their financial support of our Institute. We would also like to thank Maxime Trouillet for technical support.

\section{References}

[1] a) G. Opassi, A. Gesù and A. Massarotti, Drug Discovery Today 2018, 23, 565-574; b) J.-L. Reymond and M. Awale, ACS Chem. Neurosci. 2012, 3, 649-657; c) C. M. Dobson, Nature 2004, 432, 824-828.

[2] a) F. Lovering, J. Bikker and C. Humblet, J. Med. Chem. 2009, 52, 6752-6756; b) F. Lovering,

MedChemComm 2013, 4, 515-519.

[3] a) W. Wei, S. Cherukupalli, L. Jing, X. Liu and P. Zhan, Drug Discovery Today 2020, 25, 1839-1845; b) T. T.

Talele, J. Med. Chem. 2020, 63, 13291-13315.

[4] a) K. Hiesinger, D. Dar'in, E. Proschak and M. Krasavin, J. Med. Chem. 2021, 64, 150-183; b) R. Uprety, A. Váradi, A. Allaoa, G. N. Redel-Traub, T. C. Palmer, E. N. Feinberg, A. C. Ferris, V. S. Pande, G. W. Pasternak and S. Majumdar, Eur. J. Med. Chem. 2019, 164, 241-251; c) G. C. Geary, A. Nortcliffe, C. A. Pearce, D. Hamza, G. 
Jones and C. J. Moody, Bioorg. Med. Chem. 2018, 26,

791-797; d) A. A. Kirichok, I. O. Shton, I. M. Pishel, S. A. Zozulya, P. O. Borysko, V. Kubyshkin, O. A. Zaporozhets, A. A. Tolmachev and P. K. Mykhailiuk, Chem. Eur. J.

2018, 24, 5444-5449; e) Y.-J. Zheng and C. M. Tice,

Expert Opin. Drug Discov. 2016, 11, 831-834; f) Y. Zheng, C. M. Tice and S. B. Singh, Bioorg. Med. Chem. Lett. 2014, 24, 3673-3682.

[5] A. Sveiczer, A. J. P. North, N. Mateu, S. L. Kidd, H. F. Sore and D. R. Spring, Org. Lett. 2019, 21, 4600-4604.

[6] E. M. Carreira and T. C. Fessard, Chem. Rev. 2014, 114, 8257-8322.

[7] K. E. Soklou, H. Marzag, J.-P. Bouillon, M. Marchivie, S. Routier and K. Plé, Org. Lett. 2020, 22, 5973-5977.

[8] a) G. Müller, T. Berkenbosch, J. C. J. Benningshof, D. Stumpfe and J. Bajorath, Chem. Eur. J. 2017, 23, 703-710; b) S. Kumar, P. D. Thornton, T. O. Painter, P. Jain, J. Downard, J. T. Douglas and C. Santini, J. Org. Chem. 2013, 78, 6529-6539.

[9] C. Lalli, A. Trabocchi, F. Sladojevich, G. Menchi and A. Guarna, Chem. Eur. J. 2009, 15, 7871-7875.

[10] Y. Wang, W.-Y. Zhang and S.-L. You, J. Am. Chem. Soc. 2019, 141, 2228-2232.

[11] H. Tanaka and K. Ogasawara, Tetrahedron Lett. 2002, 43, 4417-4420.

[12] R. C. Kanamarlapudi, M. Bednarz, W. Wu and P. Keyes, Org. Process Res. Dev. 2007, 11, 86-89. 
